\title{
INDUCED SPUTUM IN HIV- INFECTED PATIENTS: DIAGNOSIS OF ACUTE PULMONARY DISEASES
}

\author{
Glória Maria de Oliveira ${ }^{1 *}$, Alexander Magno Cordeiro², Giovanni Antonio Marsico ${ }^{3}$, Juan Miguel Rentería4, Carlos Alberto Guimarães
}

Trabalho realizado no Grupo de Estudos de Revisão Sistemática do Rio de Janeiro, Rio de Janeiro, RJ

\author{
*Correspondência: \\ Serviço de Clínica Médica do \\ Hospital do Andaraí \\ Av. Maracanã, 1.481 - apto. \\ 401 \\ Rio de Janeiro - RJ \\ 20511-000 \\ gers-rio@yahoogroups.com
}

\begin{abstract}
SUMMARY
OBJEctive. To make a narrative review of the accuracy of induced sputum for diagnosis of pulmonary disease in HIV-infected patients. Data sources: The MEDLINE, LILACS, EMBASE and the Cochrane Library were searched. reference lists, abstracts of conference proceedings and scientific meetings were hand searched.

Methods. Study selection: Fifteen articles that specifically addressed the stated purpose were selected. Data extraction: Yield of sputum induction and fiberoptic bronchoscopy with bronchoalveolar lavage were analyzed using explicit methodologic to evaluate the quality of clinical trials.

Results. Sputum induction demonstrated $55.5 \%$ sensitivity and $98.6 \%$ specificity to Pneumocystis pneumonia. Sensitivity of sputum induction was significantly higher with immunofluorescence than with cytochemical staining (67.1 versus $43.1 \%)$. Sputum induction for diagnosis of bacterial pneumonia demonstrated $60 \%$ sensitivity, $40 \%$ specificity, $80 \%$ positive predictive value, $20 \%$ negative predictive value and $56 \%$ accuracy. In relation to tuberculosis, sputum induction demonstrated $36 \%$ sensitivity, $100 \%$ specificity, $100 \%$ positive predictive value and $54.2 \%$ negative predictive value.

Conclusion. Sputum induction seems to be effective and safe for diagnosis of pulmonary diseases in HIV-infected patients.
\end{abstract}

KEY wORDS: Induced Sputum. Bronchoscopy. Bronchoalveolar Lavage. HIV. Review Literature.

\section{BACKGROUND}

The spectrum of pulmonary manifestations in patients infected with human immunodeficiency virus (HIV) is broad, including many infectious and noninfectious complications. In the evaluation of an HIV-infected patient with diffuse pulmonary disease, a definitive diagnosis is preferred over empiric therapy in most patients. Patients, usually receive empiric treatment for community-acquired pneumonia or pneumocystosis, with nonresponders undergoing additional diagnostic testing ${ }^{1}$.

Pneumonia is the leading HIV-associated infection. It is estimated that $65 \%$ of the patients infected with HIV will present pulmonary involvement as their first clinical manifestation of the syndrome and that approximately $80 \%$ of these patients will present some kind of pulmonary involvement in the course of the disease ${ }^{2}$.

The spectrum of microorganisms includes bacteria, mainly Streptococcus pneumoniae, Staphylococcus aureus, Haemophilus influenzae and Mycobacterium tuberculosis. In addition, fungi such as Pneumocystis jiroveci, Cryptococcus neoformans and Histoplasma capsulatum are common HIV-associated pathogens. Diagnostic work-up relies on the epidemiology and immune status (CD4-lymphocytes count). Imaging techniques are always required, and the microbiological analysis of expectorations should be performed ${ }^{3}$.

\section{Induced sputum in HIV- infected patients}

In 1958, a simple, harmless and efficient method for artificial induction of sputum was described. It was first considered as a potentially useful method for early detection of lung cancer ${ }^{4}$.

This technique was logically extended to patients with pneumonia who had a nonproductive cough. In 1964, a study reported an experience applying this method to 15 patients with pneumonia who were unable to produce sputum voluntarily. In $13(87 \%)$ of these cases, a bacteriologic diagnosis was reported 5 .

In the mid-1980's the examination of induced sputum by inhalation of hypertonic saline solution was frequently used to diagnose pneumocystosis (PCP) in patients with acquired immunodeficiency syndrome ${ }^{6}$.

1. Mestranda do Programa de Pós-Graduação em Ciências Cirúrgicas da Universidade Federal do Rio de Janeiro - UFRJ, Rio de Janeiro, RJ

2. Mestrando do Programa de Pós-Graduação em Medicina; Cirurgia Geral da Universidade Federal do Rio de Janeiro - UFRJ e Médico do Hospital Municipal Lourenço Jorge. Rio de Janeiro,RJ

3. Livre Docência; Chefe da Divisão de Cirurgia Torácica do Instituto de Doenças do Tórax da Universidade Federal do Rio de Janeiro - UFRJ, Rio de Janeiro,RJ

4. rofessor adjunto do Departamento de Cirurgia da Universidade Federal do Rio de Janeiro - UFRJ, Rio de Janeiro,RJ

5. Livre-docente do Departamento de Cirurgia da Faculdade de Medicina da Universidade Federal do Rio de Janeiro - UFRJ, Rio de Janeiro, RJ 
Since then, this technique has emerged as a simple and noninvasive procedure, although a rather wide variation in diagnostic accuracy has been reported.

While induced sputum may be less invasive and less expensive to perform than bronchoscopy, cost is not trivial, and has been reported to be approximately $40 \%$ the cost of bronchoscopy ${ }^{7}$.

Although sputum induction appears to be a safe and relatively simple method, it is important that the staff involved at all stages of this test be properly trained ${ }^{8}$.

\section{Induced sputum in HIV- infected patients Purpose}

To make a narrative review, for clinicians and pneumologists, about the accuracy of sputum induction for diagnosis of pulmonary disease in HIV-infected patients.

\section{Data sources}

We searched the MEDLINE, LILACS, EMBASE.com and Cochrane Central Register of Controlled Trials (CENTRAL/CCTR), the Cochrane HIV/AIDS Group (1997 to January 2007). We also hand searched, without language restrictions, reference lists, abstracts of conference proceedings and scientific meetings (1997 to January 2007) and bibliographic review of textbooks and review articles. Our search strategy was: MEDLINE, "AIDSRelated Opportunistic Infections"[MeSH] AND "Sputum"[MeSH] Limits: All Adult:< 19 years, published in the last 10 years, Humans; LILACS, (aids ) or "infeccoes oportunistas relacionadas com a AIDS" [Descritor de assunto] and ( escarro induzido ) or "ESCARRO" [Descritor de assunto] and not ( criança ) or "crianca" [Descritor de assunto]; EMBASE.com: aids/exp AND sputum/ $\exp$ AND [humans]/lim AND ([adolescent]/lim OR [adult]/lim OR [aged]/lim) AND [1997-2007]; Cochrane Library: "sputum".

\section{Induced sputum in HIV- infected patients Study selection}

Several articles were independently selected and reviewed by two reviewers. Disagreement was resolved by consensus with a third party. Only studies that evaluated the yield of induced sputum in diagnosis of pulmonary disease in HIV-infected patients were included.

\section{Data extraction}

Fifteen articles that specifically addressed the stated purpose were selected: two retrospective studies comparing induced and expectorated sputum ${ }^{7,20}$, ten prospective studies investigating the diagnostic accuracy of sputum induction in comparison with fiberoptic bronchoscopy with BAL 8-12,14-16,18-21; one economic study type cost-effectiveness analysis (PCP) ${ }^{19}$; one metaanalysis of diagnostic procedures for PCP in HIV-1 infected patients ${ }^{17}$; and one evaluation of the quality of sputum from AIDS patients with pulmonary manifestations ${ }^{13}$.

\section{Results of data synthesis [Table 1]}

Five studies were about PCP 7, 16- 19 three were about tuberculosis 9, 15, 21, four were about lung diseases ${ }^{8,10,11,12}$, two about bacterial community-acquired pneumonia ${ }^{14,20}$, and one was about the evaluation of the quality of sputum ${ }^{13}$.

\section{Induced sputum in HIV- infected patients}

Sputum induction has proven useful in the diagnosis of Pneumocystis jiroveci pneumonia and mycobacterial infections, but data are scant on its use for diagnosis of community-acquired pneumonia (CAP). There was no significant difference in the sensitivity of induced and expectorated sputum for diagnosis of PCP when the direct fluorescent antibody method of staining was used ${ }^{7}$. When BAL was the gold standard, sputum induction in PCP demonstrated $55.5 \%$ sensitivity and $98.6 \%$ specificity. Sensitivity of sputum induction was significantly higher with immunofluorescence than with cytochemical staining (67.1 versus $43.1 \%$ ). In settings of $25-60 \%$ prevalence of PCP, positive and negative predictive values ranged 86-96.7 and 66.289.8 , respectively, with immunofluorescence, and 79-94.4 and $53-83.5 \%$ with cytochemical staining ${ }^{16}$.

In sputum induction for diagnosis of bacterial pneumonia, sensitivity was $60 \%$ and specificity $40 \%$; the positive predictive value (PPV) was $80 \%$, negative predictive value (NPV) $20 \%$ and accuracy $56 \%$. In addition, sputum induction with quantitative culture can be helpful for diagnosis of bacterial pneumonia in HIV-positive patients ${ }^{14}$.

Among tuberculosis HIV-seropositive patients, agreement between acid-fastbacilli (AFB) smear and culture results for sputum induction and BAL specimens were $98 \%$ and $86 \%$, respectively. The PPV of an AFB smear for diagnosis of pulmonary tuberculosis (PTB) was $100 \%$ and NPV $54.2 \%$ among seropositive patients undergoing sputum induction or BAL 9. In a setting with a high prevalence of Mycobacterium avium complex in respiratory specimens, the predictive value of the acid-fast bacilli smear for Mycobacterium tuberculosis was $92 \%$ for expectorated sputum specimens, $71 \%$ for sputum induction specimens, and $71 \%$ for BAL specimens ${ }^{21}$.

\section{Induced sputum in HIV- infected patients}

These findings reflect the different prevalence of isolation of mycobacteria other than those of tuberculosis in respiratory specimens.

Sputum induction by hypertonic saline inhalation does not improve specimen quality as indicated by the PMNs (polymorphonuclear neutrophils) / SECs (squamous epithelial cells) ratio on Gram stain ${ }^{22}$.

\section{Discussion}

We found that sputum induction is a sensitivity and specificity test to detect pulmonary disease in HIV-infected adult patients. There are several benefits of sputum induction when compared to BAL. This technique is less expensive and invasive than bronchoscopy with BAL, saves time, and is painless. Attempting induction early, preferably before starting antibiotics, may increase its diagnostic yield. Bronchoscopy is an invasive procedure and is not easily applicable on a large scale.

\section{Induced sputum in HIV- infected patients}

In PCP, sputum induction has a significant higher sensitivity with immunofluorescence staining when compared to cytochemical staining of sputum specimens ${ }^{16}$. Moreover, the decreased prevalence of PCP related to widespread use of antibiotic prophylaxis, and availability of highly active antiretroviral therapy (HAART) provide further grounds for re-evaluation of Pneumocystis jiroveci diagnosis ${ }^{16}$.

Pulmonary tuberculosis (TB) remains one of the most important health problems in the world. Nearly 2 billion people - about one third of the world's population - are infected with tuberculosis 


\begin{tabular}{|c|c|c|c|}
\hline $\begin{array}{l}\text { Author/Date/ } \\
\text { Design }\end{array}$ & Participants & Test results & Comments \\
\hline $\begin{array}{l}\text { Metersky } 1998 \\
\text { Retros } \\
\text { pective review }\end{array}$ & $\begin{array}{l}\text { Pneumocystis jiroveci pneumonia } \\
(n=45)\end{array}$ & $\begin{array}{l}\text { Diagnostic yield of first sample } \\
\text { was } 10 / 18(56 \%) \text { for induced } \\
\text { sputum, and } 14 / 27(52 \%) \text { for } \\
\text { expectorated sputum ( } p>0.05)\end{array}$ & $\begin{array}{l}\text { No difference in the sensitivity of induced and } \\
\text { expectorated sputum }\end{array}$ \\
\hline $\begin{array}{l}\text { Ortona } 1997 \\
\text { Retros } \\
\text { pective }\end{array}$ & $\begin{array}{l}\text { HIV-infected patients respiratory } \\
\text { illness }(n=125)\end{array}$ & $\begin{array}{l}\text { PCR-SHELA technique had } \\
\text { a } 100 \% \text { sensitivity and } 98 \% \\
\text { specificity in } 59 \text { bronchoalveolar } \\
\text { lavage and } 66 \text { induced sputum } \\
\text { samples (Pneumocystis jiroveci) }\end{array}$ & $\begin{array}{l}\text { A new PCR-solution } \\
\text { hybridization enzyme-linked assay (PCR-SHELA) } \\
\text { was assessed }\end{array}$ \\
\hline $\begin{array}{l}\text { da Silva } 2006 \\
\text { Cross sectional study }\end{array}$ & $\begin{array}{l}\text { HIV-positive patients pulmonary } \\
\text { disease } \\
(n=25)\end{array}$ & $\begin{array}{l}\text { Considering induced sputum } \\
\text { for the diagnosis of bacterial } \\
\text { pneumonia, sensitivity was } 60 \% \text {, } \\
\text { specificity } 40 \% \text {, the positive } \\
\text { predictive value was } 80 \% \text {, } \\
\text { negative predictive value } 20 \% \\
\text { and accuracy } 56 \%\end{array}$ & $\begin{array}{l}\text { Bronchoalveolar lavage and transbronchial } \\
\text { lung biopsy were considered the gold standards }\end{array}$ \\
\hline $\begin{array}{l}\text { Conde } 2000 \\
\text { Pros } \\
\text { pective }\end{array}$ & $\begin{array}{l}\text { Suspected pulmonary } \\
\text { tuberculosis } \\
\text { ( } n=207 \text { HIV negative and } \\
n=44 \text { HIV positive) }\end{array}$ & $\begin{array}{l}\text { Acid-fast bacilli (AFB) smear and } \\
\text { mycobacterial culture results - } \\
\text { induced (IS) and bronchoalveolar } \\
\text { lavage (BAL) - were in agreement } \\
\text { in } 97 \%(202 / 207) \text { and } 90 \% \\
\text { (186/207). The agreements } \\
\text { between AFB smear and culture } \\
\text { results for SI and BAL were } 98 \% \\
(43 \text { of } 44) \text { and } \\
86 \%(38 \text { of } 44)\end{array}$ & $\begin{array}{l}\text { There were no significant differences } \\
\text { in yields of AFB smears or cultures whether } \\
\text { obtained } \\
\text { by IS or BAL }\end{array}$ \\
\hline $\begin{array}{l}\text { Yajko } 1994 \\
\text { Retros } \\
\text { pective }\end{array}$ & $\begin{array}{l}\text { Smears and results of cultures } \\
\text { (3-year period at a hospital) }\end{array}$ & $\begin{array}{l}\text { The predictive value of the } \\
\text { acid-fast bacilli smear for } \\
\text { Mycobacterium tuberculosis } \\
\text { was } 71 \% \text { for induced sputum } \\
\text { specimens }\end{array}$ & $\begin{array}{l}\text { Setting with a high prevalence of Mycobacterium } \\
\text { avium complex }\end{array}$ \\
\hline $\begin{array}{l}\text { Chuard } 2001 \\
\text { Labora } \\
\text { tory-blinded, rando } \\
\text { mized study }\end{array}$ & $\begin{array}{l}\text { Patients with respiratory tract } \\
\text { infection productive } \\
\text { cough }\end{array}$ & $\begin{array}{l}\text { Patients were in the induced } \\
\text { ( } \mathrm{n}=58 \text { ) and spontaneous ( } \mathrm{n} \\
=62 \text { ) sputum groups. Quality } \\
\text { was assessed by evaluating the } \\
\text { ratio between polymorphonuclear } \\
\text { neutrophils and squamous } \\
\text { epithelial cells on Gram-stained } \\
\text { specimens }\end{array}$ & $\begin{array}{l}\text { Sputum induction by hypertonic saline inhalation } \\
\text { does not improve specimen } \\
\text { quality }\end{array}$ \\
\hline
\end{tabular}

bacteria ${ }^{23,24}$. Each year, Nearly 9 million people develop active tuberculosis, the infectious form of the disease, every year, and 2 million people experience TB-related deaths each year ${ }^{25}$.

In Brazil, with an estimated annual prevalence of 129,000 new cases of TB, approximately $22 \%$ of adult patients with suspected pulmonary tuberculosis do not produce sputum spontaneously 9.Sputum induction is a safe procedure with high diagnostic yield and good agreement with results from fiberoptic bronchoscopy 9. Thus, sputum induction is a valuable tool for diagnosing pulmonary tuberculosis.

Use of HAART in a region with a high incidence of TB may reduce the risk of this disease among HIV-infected patients. The use of HAART was associated with an $81 \%$ reduction in risk of TB ${ }^{26}$. Free access to HAART may contribute to reduce the incidence of TB in populations with a low socioeconomic level and high prevalence of coinfection with HIV and M. tuberculosis ${ }^{26}$.

\section{Induced sputum in HIV- infected patients}

Although a reduction in the risk of tuberculosis was not initially apparent, recent reports from large observational studies performed in Europe, have suggested that antiretroviral therapy has a protective effect ${ }^{27}$. If the prevalence of TB with HAART is reduced, we do not know whethetr sputum induction would have the same diagnostic accuracy.

Patients who underwent sputum induction experienced side effects in a way similar to patients who had bronchoscopy with BAL ${ }^{9}$. It is recommended that sputum be processed as soon as possible or within two hours, in order to ensure optimum cell 
counting and staining ${ }^{23}$. If the specimen of sputum induction is negative, then bronchoscopy with BAL should be performed. Transbronchoscopic surgical lung biopsy is seldom needed.

\section{Conclusion}

Sputum induction is effective to obtain sputum in HIV-infected patients who fail to expectorate. For these patients sputum induction may be a technique that is safe and easily performed, with a good diagnostic yield.

\section{ACKNOWLWDGMENTS}

We thank Sonia M. R. Vasconcelos (UFRJ) for the critical review of this manuscript.

\section{Conflict of interest: none}

\section{Resumo}

\section{ESCARRO INDUZIDO NOS PACIENTES INFECTADOS PELO HIV: DIAGNÓSTICO DAS DOENÇAS PULMONARES AGUDAS}

OBJETIVo. Realizar uma revisão narrativa sobre a acurácia do escarro induzido no diagnóstico da doença pulmonar nos pacientes infectados pelo HIV. Fontes de dados: pesquisamos na MEDLINE, LILACS, EMBASE e Cochrane Library. Foi realizada busca manual nas listas de referências e em resumos de anais e conferências em congressos.

Métodos. Seleção dos estudos: foram selecionados 15 artigos que se relacionavam ao objetivo proposto. Extração dos dados: analisamos o rendimento do escarro induzido e da broncofibroscopia com lavado broncoalveolar, empregando critérios metodológicos na avaliação da qualidade dos ensaios clínicos.

RESULTADOS. O escarro induzido mostrou uma sensibilidade de $55,5 \%$ e especificidade de $98,6 \%$ no diagnóstico da pneumocistose; a sensibilidade do escarro induzido foi significativamente maior com a imunofluorescência do que com a coloração citoquímica (67,1 vs. 43,1\%). O escarro induzido para o diagnóstico de pneumonia bacteriana mostrou uma sensibilidade de $60 \%$, um especificidade de 40\%, um valor preditivo positivo de $80 \%$, um valor preditivo negativo de $20 \%$ e uma acurácia de $56 \%$. Com relação à tuberculose, o escarro induzido mostrou uma sensibilidade de $36 \%$, uma especificidade de $100 \%$, um valor preditivo positivo de $100 \%$ e um valor preditivo negativo de $54,2 \%$.

Conclusão. O escarro induzido parece ser efetivo e seguro no diagnóstico das pneumopatias nos pacientes infectados pelo HIV. [Rev Assoc Med Bras 2009; 55(5): 617-20]

UnITERMOS: Escarro induzido. Broncoscopia. Lavado broncoalveolar. HIV. Literatura de revisão.

\section{REFERENCES}

1. Narayanswami G, Salzman SH. Bronchoscopy in the human immunodeficiency virus-infected patient. Semin Respir Infect. 2003;18:80-6.

2. Suffredini AF, Masur H. Pulmonary dysfunction in patients infected with human immunodeficiency virus. In: Pennington JE, editors. Respiratory infections: diagnosis and management. $2^{\text {nd }}$ ed. New York: Ra ven Press; 1988. p. 241-63.

3. Zimmerli W. Pneumonia in patients with HIV infection. Ther Umsch. 2001;58:620-4

4. Bickerman HA, Sproul EE, Barach AL. An aerosol method of producing bronchial secretions in human subjects: A clinical technique for the detection of lung cancer. Dis Chest. 1958;33:347-62.

5. Jones Jr FJ, Avallone CJ.. The value of sputum induced by heated hypertonic aerosol inhalation in the management of pneumonia. Chest. 1964;45:612-5.
6. Bigby TD, Margolskee D, Curtis JL, Michael PF, Sheppard D, Hadley WK, et al.The usefulness of induced sputum in the diagnosis of Pneumocystis carinii pneumonia in patients with the acquired immunodeficiency syndrome. Am Rev Respir Dis. 1986;133:515-8.

7. Metersky ML, Aslenzadeh J, Stelmach P. Pneumocystis carinii pneumonia: A comparison of induced and expectorated sputum for the diagnosis of Pneumocystis carinii pneumonia. Chest. 1998;113:1555-9

8. Benito N., Rañó A., Moreno A., González J., Luna M., Agustí C, .et al. Pulmonary infiltrates in HIV-infected patients in the highly active antiretroviral therapy era in Spain. J Acquir Immune Defic Synd. 2001:27:35-43.

9. Conde MB, Soares SLM, Mello FCQ, Rezende VM, Almeida LL, Reingold AL, et al. Comparison of sputum induction with fiberoptic bronchoscopy in the diagnosis of tuberculosis: Experience at an acquired immune deficiency syndrome reference center in Rio de Janeiro, Brazil. Am J Respir Crit Care Med. 2000;162:2238-40.

10. Ersch J, Speich R, Weber R, Altwegg M, Hauser M. The value of bronchoalveolar lavage in the clarifying of HIV-associated lung diseases Dtsch Med Wochenschr. 2000:125:789-93

11. Silva RM and Chterpensque A. Bronchofibroscopy in the etiologic diagnosis of lung diseases in patients with acquired immunodeficiency syndrome. Rev Assoc Med Bras. 2000:46:174-6.

12. Silva RM, Moreira PJZ, Silva J. Induced sputum for the diagnosis of lung disease in HIV-positive patients. J Bras Pneumol. 2004;30:452-8.

13. Rolo Filho M, Pereira LFM, Rodrigues MP. Avaliação da qualidade do escarro de pacientes com manifestação pulmonar decorrente de Aids, para procedimentos bacteriológicos, no Distrito Federal. Rev Saúde Dist Fed. 1998;9:13-9.

14. Silva RM, Teixeira PJZ, Zimermann J, Moreira JS. The clinical utility of induced sputum for the diagnosis of bacterial community-acquired pneumonia in HIV-infected patients: a prospective cross-sectional study. Braz J Infect Dis. 2006;10:89-93.

15. Vargas D, Garcia L, Gilman RH, Evans C, Ticona E, Navincopa M, et al. Diagnosis of sputum-scarce HIV-associated pulmonary tuberculosis in Lima, Peru. Lancet. 2005;365(9454):150-2.

16. Ortona E, Margutti P, Tamburrini E, Mencarini P, Visconti E, Zolfo M, et al. Detection of Pneumocystis carinii in respiratory specimens by PCR-solution hybridization enzyme-linked immunoassay. J Clin Microbiol. 1997;35:1589-91.

17. Cruciani M, Marcati P, Malena M, Bosco O, Serpelloni G, Mengoli C. Metaanalysis of diagnostic procedures for Pneumocystis carinii pneumonia in HIV1-infected patients. Eur Respir J. 2002;20:982-9.

18. ODonnell WJ, Pieciak W, Chertow GM, Sanabria J, Lahive KC. Clearance of Pneumocystis carinii cysts in acute $P$ carinii pneumonia: assessment by serial sputum induction. Chest. 1998;114:1264-8.

19. Chouaid C, Housset B, Lebeau B. Cost-analysis of four diagnostic strategies for Pneumocystis carinii pneumonia in HIV-infected subjects. Eur Resp J.1995;8:1554-8.

20. Bandyopadhyay DA, Gerardi ML, Metersky A. Comparison of induced and expectorated sputum for the microbiological diagnosis of community acquired pneumonia. Pulmonary Division, University of Connecticut School of Medicine, Farmington, Conn and Hospital for Special Care, New Britain, Conn., USA. Respiration. 2000;67:173-6

21. Yajko DM, Nassos PS, Sanders CA, Madej JJ, Hadley WK. High predictive value of the acid-fast smear for Mycobacterium tuberculosis despite the high prevalence of Mycobacterium avium complex in respiratory specimens. Clin Infect Dis. 1994;19:334-6.

22. Chuard C, Fracheboudb D, Regameya C. Effect of sputum induction by hipertonic saline on specimen quality. Diagn Microbiol Infect Dis. 2001;39:211-4.

23. American Colleges of Chest Physicians. Northbrook: ACCP; c1997-2007 [updated 2002]. Pulmonary and Critical Care Update [cited 2007 Jul 22]. Available from: http://www.chestnet.org/education/online/pccu/vol16/lessons3_4/ lesson04.php.

24.Jensen PA, Lambert LA, Iademarco MF, Ridzon R. Guidelines for Preventing the Transmission of Mycobacterium tuberculosis. MMWR Morb Mortal Wkly Rep. 2005;54(RR17). [cited 2007 Jul 22]. Available from: http://www.cdc.gov/ $\mathrm{mmwr} /$ preview/mmwrhtml/rr5417a1.htm.

25. CDC Division of Tuberculosis Elimination (DTBE) [cited 2007 Aug 4].Available from: http://www.cdc.gov/tb/WorldTBDay/default.htm.

27. Santoro-Lopes G, de Pinho AMF, Harrison LH, Schechter M. Reduced risk of tuberculosis among brazilian patients with advanced human immunodeficiency virus infection treated with highly active antiretroviral therapy. Clin Infect Dis. 2002;34:543-6

28. Girardi E, Antonucci G, Vanacore P, Libanore M, Errante I, Matteelli, A et al. Impact of combination antiretroviral therapy on the risk of tuberculosis among persons with HIV. In: Proceedings of the 7th Conference on Retroviruses and Opportunistic Infections; 2000 Jan 30-Feb 2; San Francisco. [Abstract n. 255]. Available from: http://gateway.nIm.nih.gov/MeetingAbstracts/102243133.html.

Artigo recebido: 07/07/08

Aceito para publicação: 07/03/09 